
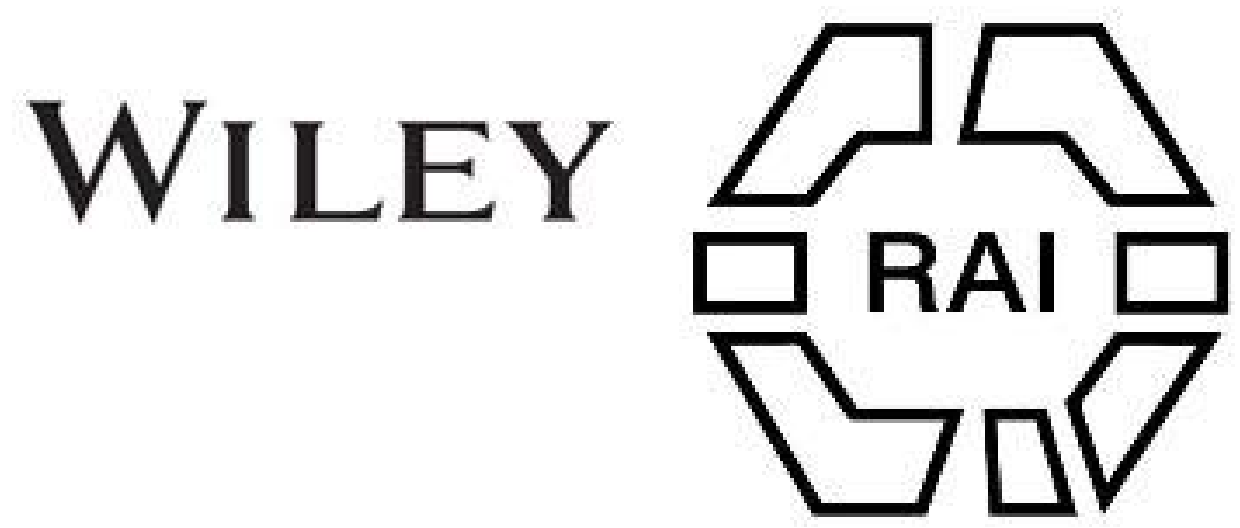

\title{
63. Quartz Implements from Ceylon.
}

\section{Author(s): C. G. Seligmann}

Source: Man, Vol. 8 (1908), pp. 113-116

Published by: Royal Anthropological Institute of Great Britain and Ireland

Stable URL: http://www.jstor.org/stable/2840788

Accessed: 27-06-2016 03:30 UTC

Your use of the JSTOR archive indicates your acceptance of the Terms \& Conditions of Use, available at

http://about.jstor.org/terms

JSTOR is a not-for-profit service that helps scholars, researchers, and students discover, use, and build upon a wide range of content in a trusted digital archive. We use information technology and tools to increase productivity and facilitate new forms of scholarship. For more information about JSTOR, please contact support@jstor.org.

Wiley, Royal Anthropological Institute of Great Britain and Ireland are collaborating with JSTOR to digitize, preserve and extend access to Man 


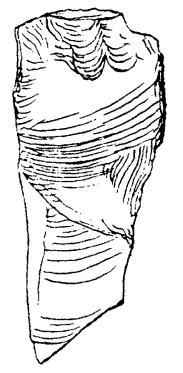

I

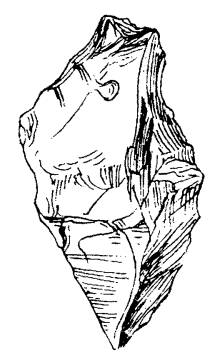

5

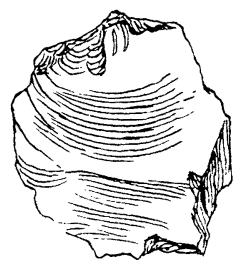

2

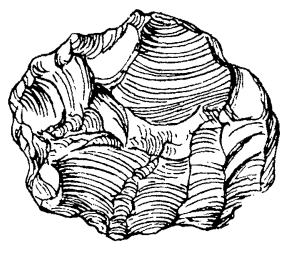

6

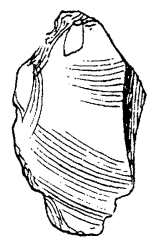

3

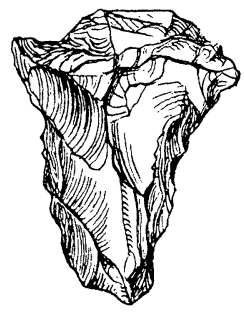

7

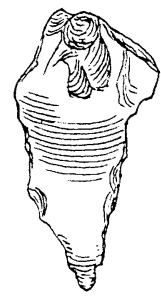

4

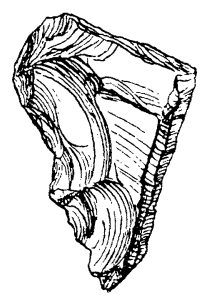

8

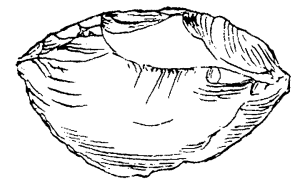

9

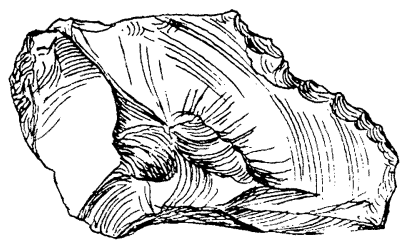

IO

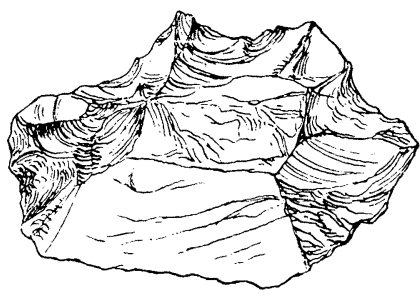

I 3

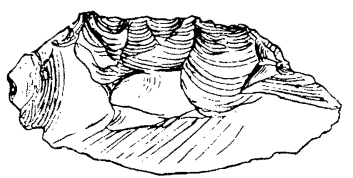

I I

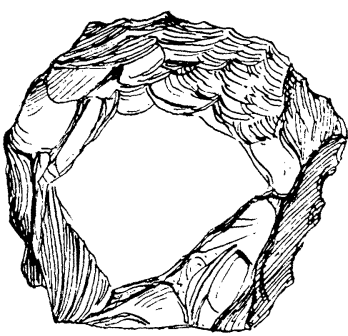

14

QUARTZ IMPLEMENTS FROM CEYLON. 


\section{Ceylon. \\ ORIGINAL ARTICLES. With Plate $\mathrm{H}$. \\ Seligmann. \\ Quartz Implements from Ceylon. By C. G. Seligmann, M.D. \\ Plate H. represents a number of pieces of worked quartz from Ceylon, the 10} majority from the collections made by Messrs. E. E. Green and J. Pole, who were the first to recognise that quartz fragments of the type shown were, in fact, stone implements. Such quartz implements have now been found in a considerable number of localities in the island ranging from a height of a few hundred feet above sea level to about 4,000 feet. Further, the circumstances under which they have been found suggest that they may have been in use about 2,000 years ago or somewhat earlier.

Before indicating the facts which seem to warrant this idea it will be convenient to state the places in which implements of the type figured have been found.

Mr. Green has collected them from the neighbourhood of Peredeniya, near Kandy, at a height of about 1,500 feet above sea level, and this is the place of origin of the well-

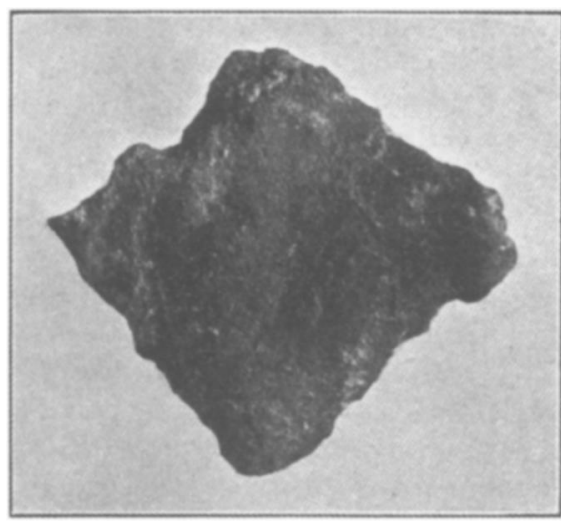

FIG. 1. worked stone shown in Pl. H., Fig. 6. He has also found them at Pundalnoya, about 4,000 feet above sea level and some twelve miles from Nuwera Eliya. Mr. Pole has made a large collection from the neighbourhood of Maskeliya at an altitude of 2,000 to 3,000 feet, and has also found specimens near Matale. Drs. F. and P. Sarasin have recorded quartz implements from caves they explored near Nilgala village in Uva Province at a height of about 800 feet, from Kallodi in the Eastern Province, and from Kataragam on the borders of Uva and the Southern Province. The writer has fcund them near Bandarawella in Uva on the bare grassy hillocks called patanas at a height of over 4,000 feet, and has dug specimens from a cave, still used by Veddas, situated in the park country at a height estimated at about 500 feet above sea level in that part



FIG. $1 a$. of the Uva jungle known as Henebedda.

'This cave is one of two rock shelters formed by a single mass of rock ; it has a wellcut drip ledge in no respect differing from those admittedly cut by Sinhalese about the time that Buddhism was introduced into the island, and two square sockets are cut in its roof resembling those discovered by $\mathbf{M r}$. F. Lewis at Nuwaragala and figured by him.* Further, there are three steps cut in the solid rock (Fig. 2) between this rock shelter and the second cave, which is separated from it only by that portion of rock in which the steps are hewn. 'Ihese steps and the upper of the two caves are shown in Fig. 2 ; but three other steps, which can scarcely be seen in the photograph, exist in the rock slope between the tree trunk and the crouching dog. There is ne inscription on the rocks of either of these caves, but below the drip ledge of a rock shelter used by the same Veddas, and not more than an hour's walk

\footnotetext{
* "Nuwaragala, Eastern Province" [Journ. Roy. As. Soc. (Ceylon Branch), Vol. XIX., 1907].
} 
from Bendia Galge (as the first described caves are called), there is an inscription of which Mr. H. C. P. Bell, archæological commissioner, says, "The Brâhmi" [characters] "are of the oldest type, therefore B.c." 'This inscription has been read by the same authority, to whom my best thanks are due, as "(cave of) the chief . . . son of the chief Vela." There is thus reason to suppose that the Bendia Galge caves were used by Sinhalese some 2,000 years ago, and this renders the result of a partial excavation, which was all for which there was time, of special interest.

The nature of its bottom made the lower cave the easier to examine, accordingly a longitudinal trench about a foot wide was dug in the long axis of the lower cave. The first six inches yielded fragments of pottery and a number of bones, a much rusted catty, and an areca nut catter both of the pattern in common use. A good many fragments of charcoal were found in the upper 12-18 inches, and several pieces of iron slag-perhaps six in all-as well as a number of land shells lying in groups, were found at a depth of from one to two feet. Bones and fragments of pottery continued to occur until a depth of about two feet was reached. Massive rock, which was taken to be the bed rock of the cave, was reached at about $2 \frac{1}{2}$ feet, and within a few inches of this were found many fragments of quartz-some milky, some ice-clear, some faintly opalescent, some smokey, and some amethystine. A few of these were as big as hen's egrs, the majority varied from the size of an apricot to a haricot bean, some were even smaller. From the large number of pieces of quartz-nearly 300-collected at the depth mentioned from this trench, and a small trench driven at right angles to it,

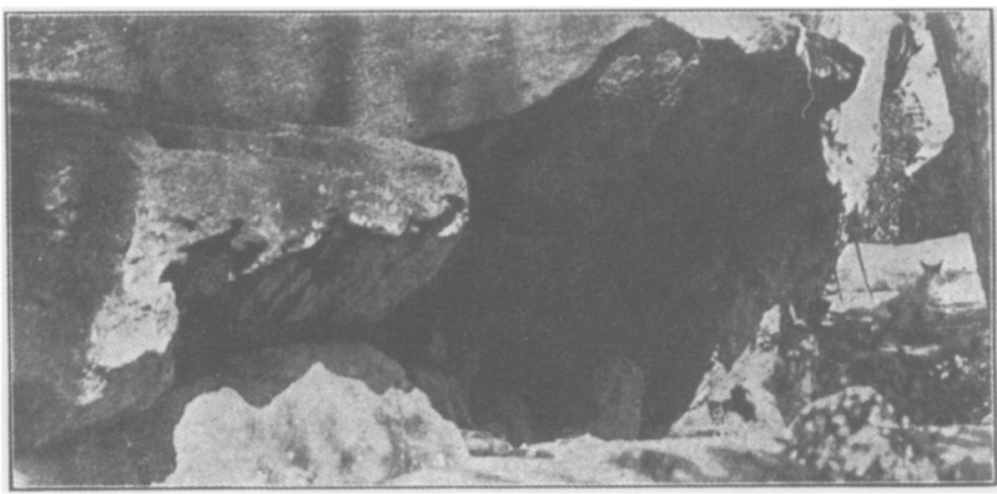

FIG. 2.

as well as from the absence of pieces of country rock, there can be no doubt that these pieces of quartz were brought to the site in which they were found by man. They were not waterworn, and the variety of colour and opacity they presented make it certain that they had not weathered out in situ, in spite of the fact that quartz (but not as far as I could determine, ice-clear quartz) occurs in segregation masses in the gneissic rock of the neighbourhood. Further, when all the fragments were carefully washed and examined it was found that some 3 per cent. of the pieces of quartz obtained from this cave showed signs of working. They are, in fact, implements similar to those shown me by Messrs. Green and Pole. Additional proof that the fragments of quartz had been brought by man to the site on which they were found were afforded by some irregular digging done in the upper caveshown in Fig. 2-formed by the same rock mass as the lower cave, and separated from it only by a few feet. 'The floor of this cave was so rocky that a regular trench could not be dug, but a number of holes, the largest perhaps 6 feet by 4 feet, were dug down to what was apparently the country rock at the bottom of the cave. Fragments of pottery and the bones of animals were found in plenty in these holes, but altogether they yielded only four pieces of quartz, namely, two waterworn pebbles and two broken pieces of clear glassy quartz. As in the lower cave, so in this cave, a few small pieces of slag were found some 18 inches to 2 feet below the level of the surface. 
Nothing that could be regarded as a core or hammer-stone was recognised among the quartz excavated, and no pieces of chert or jasper occurred in this cave, nor have Messrs. Green and Pole found chert or jasper implements on the sites from which their collections were made. Cores, as far as my experience goes, are, in fact, not very commonly found. Mr. Green's collection contains one excellent specimen, there are a few in Mr. Pole's collection of upwards of 1,000 specimens, and I picked up one near Bandarawella. Jasper implements were found in abundance by the Sarasins, and they collected "as many as forty" stone hammers, i.e., presumably hammerstones.* Worked chert does, however, occur in Ceylon. Figs. 1 and $1 a$ represent a specimen found by Mr. James Parsons, bead of the Mineral Survey, concerning which he says, "It was found

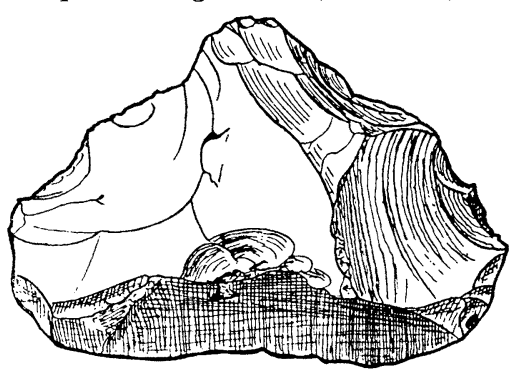

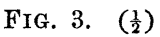
" at Ranchigoda, Makara District, in the Southern Province, in river-gravel under " about three feet of soil. There was no more chert in the gravel, which was of " white quartz. Silicified rock was found in the neighbourhood but no chert of this " type." Again, while at Nilgala a large piece of stone-apparently chert-was brought to me as having been found in a river bed. This stone is reproduced in Fig. 3 ; it has somewhat the appearance of a broken palæolith, and is about 10 centimetres broad. A number of flakes have been struck from one surface, but

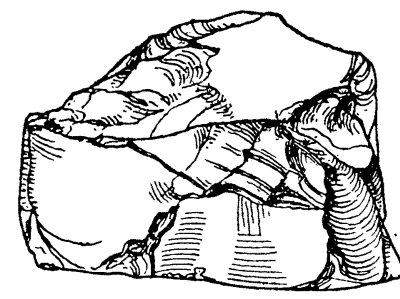

FIG. 4. (1) its edge has not been worked. It is well patinated, and, in spite of its resemblance to the stone implement, it may be nothing more than a stone portion of a " flint and steel," such as are in use at the present day among the more backward of the peasant Sinhalese.

As regards the type of the quartz implements, there seems no good reason to consider these other than neolithic, though in Ceylon, in a recent newspaper discussion, they have been spoken of as palæolithic and even eolithic.

Fourteen of the quartz implements are figured on Plate H. Of these Nos. 1-5, 7, 10, and 14 are worked on one side only; the unworked side of Nos. 1-4 is shown in order to illustrate the well-marked bulb of percussion which distinguishes many of the specimens. The general characteristics of the instruments may be gathered from the illustration, so that a description in detail is hardly necessary. Attention may, however, be called to the three last specimens figured; of these No. 12 shows a large portion of the original crust, and appears to have been much rolled; No. 13 belongs to a type of which hundreds of examples. occur among European stone implements, and No. 14, again, has many parallels among the implements from this continent: this specimen is rather thicker than the rest, and measures $15 \mathrm{~mm}$. from one face to the other.

The localities where the various specimens were collected are as follows:-Nos. 2 and 3 were collected by me at Bandarawella, No. 6 by Mr. Green at Peradeniya, No. 7 by me near Bibile, and the remainder by Mr. Pole in the neighbourhood of Maskeliya. The cores figured in the text were found

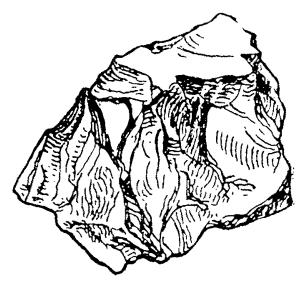

Fig. 5. ( $\left.\frac{1}{1}\right)$ respectively at Peradeniya and near Maskeliya-the first, Fig. 4, by Mr. Green; the second, Fig. 5, by Mr. Pole.

* Spolia Zeylonica, Colombo, 1907. Vol. IV., p. 197. 
From these facts it appears that at one time there must have been in Ceylon a considerable population who worked quartz, and that this people was widely distributed, extending at least from the Southern into the Central and Eastern Provinces and occupying heights varying from the low forest country of the Eastern Province to at least 4,000 feet. The material they used is refractory and does not occur in large masses. The latter factor probably accounts for the small size of the implements they produced, and also probably for the rough nature of most of them; but when the best samples of their work is examined it appears that their industry was neolithic. Whether or no the quartz workers actually were Veddas, as suggested by the Sarasins, and, as seems reasonable enough, they occupied the caves used recently and at the present day by the Veddas of Uva, and, since these caves present undoubted evidence of being used by the Sinhalese of about 2,000 years ago, it may be presumed that the Sinhalese turned the cave-dwellers out of their rock shelters, or, perhaps, peaceably occupied these, and that when the Sinhalese neglected the part of Uva in which the caves are found the cave-dwellers drifted back to them.

But the cave-dwellers of the present day are Veddas, and there is evidence that three or four centuries ago there was a strong Vedda population in the country extending from the neighbourhood of the caves in Uva to Matale in the Central Province. Taken with the inscription in Bendia Galge cave, in which the common Vedda name Nila is mentioned, this suggests that the quartz workers were, in fact, Veddas. If this be so it appears to indicate a much older and more intimate association between cave-dwelling Veddas and the Sinhalese than is usually realised, and there are other facts which seem to me to point to this conclusion.

My best thanks are due to Messrs. Green and Pole for permitting me to make free use of their collections.

C. G. SELIGMANN.

Japan.

Aston.

A Japanese Book of Divination. By W. G. Aston, C.M.G.

At all times and in all countries the soothsayer has a very good opinion of

himself and his office. "I am Sir Oracle," he announces to a more or less credulous public, "and when I ope my lips let no dog bark." The author of the work before me is no exception to this rule. He expects the reader "to cleanse himself, rinse his mouth, " wash his hands, and raise the book three times reverently to his forehead before he " opens it." He must not put it down on the bare mats but on a pure stand with a sheet of paper under it. I am afraid my copy has not been always treated with such reverent care. It is soiled, worn, and dog's-eared. A more serious matter is that of the two volumes of which it consists one is missing. Nevertheless a sufficiently clear idea of its general scope and character is to be obtained from what is left.

Divination is of two kinds-the religious, as the Delphian oracle, and the nonreligious, exemplified by our chiromancy. In the present work we find a combination of both principles. It has a non-religious basis, which is fortified by the addition of various religious elements. The non-religious principle is that universally recognised in the casting of lots, viz., a belief in the virtue of mere chance. The necessary mechanism consists of a set of 100 divining sticks resembling chopsticks. They are about 6 or 7 inches in length, and each bears a number with an inscription in the Chinese character signifying "Great Good Luck," "Small Good Luck," "Bad Luck," "Ultimate Small Good Luck," or "Half Good Luck." The lucky numbers greatly preponderate. These sticks are placed in an oblong box measuring 12 by 4 by 4 inches. It is closed on all sides except for a small hole at the end, which allows only one stick to come out at a time. I have seen a box of this kind which was provided for the use of visitors to a Buddhist temple at Ishiyama, near Otsu. It contained twelve sticks only. On drawing one the consulter of the oracle received a slip of paper 